\title{
Indonesian Speech Act and Imperative Entity Analysis in TV ONE Indonesian Lawyers Club of June $7^{\text {th }}, 2016$
}

\author{
Bunga Diantirta Yapati Puteri, Universitas Airlangga
}

\begin{abstract}
This analysis is related to the political speech acts that are used by the politician and the government officer in the Indonesian Lawyers Club (ILC) program, one most favorite program in TV ONE (one of the private television broadcasters in Indonesia). For this research, the qualitative data are used to know the description of pragmatic elements or entities that involved in the political language or speech acts. Analyzing the data that are compiled from the ILC program of TV ONE (especially the data of 7 June 2016 edition), the researcher applied the descriptive qualitative approach. In that program of TV One, there are some pragmatic entities that are applied; they are the direct speech act (the non - literal speech act), the cooperative principles and Grice maxims, the imperative entities, and the politeness strategies
\end{abstract}

Keywords: Indonesian Lawyers Club; political speech act; speech act

\section{Introduction}

One of the most important communication functions is to maintain the continuity of relationships among its communicants (Wardaugh, 1986: 233). Concerning this, one can conclude that the important thing in communication is to maintain harmony between the speaker and the other person. On the other hand, that language used as the medium must contain complex rules on how one should speak to the interpersonal relations of the perpetrators to be preserved.

In other words, in implicit communication, there is a rule on how a person should behave or speak or act speech and how he should be treated by his interlocutor. In relation to this, the rules controlling the manner of communicating differ from one society to other society, or more precisely between languages and other languages. Nevertheless, there are, principally, universal principles of universal communication that can be applied in any language society in the world. For that matter, in sociolinguistic, pragmatic, and sociopragmatic studies, for example, there is a politeness marker or a politeness strategy or principles of politeness. For example, in the realm of the Javanese and Sundanese languages, the politeness marker appears in the language-level system (undha-usuk system), especially from the lowest linguistic level to the highest level.

Correlating to the above statement, in pragmatics or sociopragmatics, the markers or principles of politeness are more visible in the strategies pursued by its speakers in producing various types of speech. Accordingly, it is said that pragmatics is the study of the strategy of telling (Verhaar, 1996) and this speech strategy is called rhetoric (Leech, 1983). In this paper, one of the highlights will become one of the communication strategies adopted by language users, especially speech acts used by some lawyers and politicians in the program of Indonesia Lawyers Club in TV ONE, especially in the edition on June 7, 2016.

Furthermore, in discussing speech acts used by officials and politicians at the Indonesian Lawyers Club program, the researcher describes some of the Indonesian imperative entities and their modest forms of politeness. The reason why this paper also discusses the above topic is because the imperative entity is certainly always present in a fairly high level of frequency (C. F. Rahardi, 2004; Rahardi, 2006). Imperative entities are often present in everyday communication, especially in the context of relationships among human beings. In this regard, the subject of the imperative entities carried out in this study essentially uses a sociopragmatic approach.

This paper aimed to answer two research problems; 1) How the speech acts and Indonesian imperative entities are used by lawyers and politicians in the Indonesian Lawyers Club TV ONE program? 2) What kinds of speech acts and Indonesian imperative entities are found in the Indonesian Lawyers Club TV One? 


\section{Theoretical reviews}

\subsection{Kinds of speech acts}

Wijana (1996: 30) explains that the type of speech act can be distinguished into direct speech acts and indirect speech acts, and the act of literal speech and speech act is not literal.

\subsubsection{Direct and indirect speech acts}

Direct speech act is a speech act whose sentence mode reflects the intent of the speaker (Wijana, 1996: 30). The declarative sentence is used to preach something (information), the interrogative sentence is used to ask something, and the command sentence (imperative) is used to declare a command, solicitation, asking, or request. The form of the direct speech acts can be seen in the following examples.

(1) Pak Karto ngingu sapi telu.

'Pak Karto memelihara sapi tiga ekor.'

(2) Kowe mangkat sekolah jam pira?

'Kamu berangkat sekolah jam berapa?'

(3) Jogan kae sapunen!

'Lantai itu bersihkan!

Indirect speech act is a speech act that is understood and accepted not in accordance with the direct utterances. For example, the intent of governing is phrased with sentences with newsletters or questions that the governed do not feel that they are governed (Wijana, 1996: 30). The form of indirect speech acts can be seen in this example.

(4) Ana es dawet neng kulkas.

'Ada es dawet di kulkas.'

(5) Neng endi bukune?

'Di mana bukunya?'

Example (4) is not just to inform you that there is ice dawet in the refrigerator, but the speech is meant to offer the opponent to take ice dawet to drink. Example (5) does not only serve to ask where the book is, but indirectly tells the other person to get the book.

\subsubsection{The literal and non-literal speech acts}

The literal speech act is a speech act which means the same as the meaning of the words that form it. Meanwhile, the non-literal speech act is the act of speech which means not the same as or contrary to the meaning of the words that form it (Wijana, 1996: 32). The form of literal and non-literal speech acts can be seen in the following example.

(6) Lagune serokke! Lagune pengen tak catet.

Lagunya keraskan! Lagunya pengen aku catat.

(7) Lagune kurang seru. Serokke maneh. Aku pengen turu.

Lagune kurang keras. Keraskan lagi. Aku ingin tidur.

Speech in Example (6) is a literal speech act. The act of speech in Example (7) is a non-literal speech act. If the act of direct speech and speech act is not directly interacted with literal and nonliteral speech acts, it will create this speech act.

\section{(a) The direct literal speech act}

The direct literal speech act is a speech act that is expressed by the mode of speech and means the same as the meaning of the utterance. The purpose of commanding is delivered with the sentence of the command, preaching with the sentence of the news, asking something with the interrogative sentence (Wijana, 1996: 33). The form of literal direct speech acts can be seen in the following example.

(8) Jupukke tas kuwi!

'Ambilkan tas itu!'

(9) Setiawan bocah sing pinter.

'Setiawan anak yang pintar.

Examples (8) and (9) are literal direct speech acts. Example (8) is meant to have the opponent to take a briefcase that is phrased with a command line. Example (9) is meant to proclaim that Setiawan is a clever child which is phrased with a declarative sentence. 


\section{(b) The indirect literal speech act}

The indirect literal speech act is a speech act expressed by a sentence mode that is inconsistent with the meaning of the utterance, but the meaning of the words that pertains in accordance with what the speaker means (Wijana 1996: 34). The form of indirect literal speech acts can be seen in the following example.

(10) Sabune neng endi?

'Sabunnya di mana?'

Example (10) is an indirect literal speech act. The meaning of commanding for taking a soap is asking something indirectly, yet it is using interrogative sentence.

\section{(c) The direct non-literal speech act}

The direct non-literal speech acts are speech acts expressed in sentence mode corresponding to the meaning of speech, but the words that compose them have no meaning in common with the intention of the speaker (Wijana 1996: 35). The form of direct non-literal speech acts can be seen in the following example.

(11) Gambarmu apik, kok.

Gambarmu bagus, kok.

Example (11) is a direct non-literal speech act. The speech act means the picture of the opponent is not beautiful.

\section{(d) The indirect non-literal speech act}

Indirect non-literal speech act is a speech act expressed by the sentence mode and meaning of sentences that are not in accordance with the intention to be expressed (Wijana, 1996: 36). The forms of indirect non-literal speech acts can be seen in the following example.

(12) Latare resik tenan Ndhuk.

'Halamannya bersih sekali Nak.'

Example (12) is an act of indirect non-literal speech act. Speech is used by parents to have a child sweep the dirty yard.

\subsection{Grice Cooperative Principles}

Grice argues that in order to carry out the principle of cooperation, every speaker must observe 4 (four) conversational maxims, namely:

\section{a) Quantity Maxim}

Maksim quantity requires each participant to contribute as much as needed by the interlocutor. For example, a speaker who speaks fairly will certainly choose the sentence (1) below instead of sentence (2).

1) My neighbor is pregnant.

\section{b) Quality Maxim}

2) My neighbor who is pregnant is a woman.

Maxim quality requires that each participant of the conversation should be based on sufficient residence. For example, one must say that the capital city of Indonesia is Jakarta instead of other cities. However, in the case of the opposite, there are certainly reasons why such a thing can happen. For this please note the conversation below.

1) Teacher : "Coba kamu, apakah ibukota Bali?"

Bunga: "Surabaya, Bu Guru."

Teacher : "Bagus, kalau begitu ibukota Jawa Timur itu Denpasar, ya?"

In the conversation above, it seems that the teacher violates the maxim of quality. Teacher said the capital of East Java is Denpasar and not Surabaya. An answer that ignores this maxim of quality is expressed as a reaction to Bunga's wrong answer. With this answer Bunga as an individual possessing a communicative competence then immediately finds an answer why his teacher made the wrong statement (why the teacher's phrase was expressed in a different tone). With sufficient evidence Bunga finally found out that the answer to his teacher's question was wrong. The good word from the teacher is not used to praise, but instead to mock or quip. Thus, there is a pragmatic reason why the teacher in the conversation above contributes to violating the maxim of quality. 


\section{c) Relevance Maxim}

Maxim relevance requires that each participant of the conversation makes a contribution relevant to the issue of the conversation

\section{d) Implementation Maxim}

Implementation Maxim requires that each participant of the conversation speaks directly, the conversation is not vague, not ambiguous, and not exaggerated and must be coherent.

\subsection{Positive politeness and negative politeness}

Politeness or etiquette is the ordinance, custom, or habit prevailing in society. Dignity is a set of rules of conduct that is agreed by a particular society. This kind of politeness is commonly called manners.

"Polite behaviour is equivalent to socially correct or appropriate behaviour: other considers it to be the hallmark or the cultivated man or woman. Some might: characterize a polite person as always being considerate towards other people: others might suggest that a polite person is self-effacing.” (Watt, 2003:1)

Fraser (in Gunarwan, 1994) defines politeness as property associated which is neither exceeded any right nor failed to fullfill any obligation. In other words, politeness is a property associated with speech and in this case from the listener's point of view, the speaker does not transcend his rights or does not deny fulfilling his obligations.

Some reviews of Fraser's definition of politeness are first, politeness is the property or part of speech not merely the speech itself. Second, it is the opinion of the hearer that determines whether politeness exists in an utterance. An utterance may mean to be a polite speech by the speaker, but in the ears of the hearer it does not sound polite and vice versa. Third, politeness is associated with the rights and obligations of the participants in the interaction. That is, whether an utterance sounds polite or not, it is measured by (1) whether the speaker does not transcend his or her rights to the other person and (2) whether the speaker fulfills his or her obligations to the other person.

According to Leech (1993) and Brown and Levinson (in Wijana, 1996) the principle of cooperation as proposed by Grice in real communication is often violated or not obeyed by the participants. This is because in communication, we do not only convey information, but also maintain the social relations between speakers and listeners (although there are certain events that do not require maintenance of that relationship). The need for non-information is included in the communicative needs of the universe.

Speech theory of language according to Brown and Levinson deals with face. The face (in a figurative sense) must be maintained, nurtured, respected, and so on. According to them, face can be distinguished into negative face and positive face.

Negative face refers to the image of every person who wishes to be rewarded by allowing him to be free to do his actions or to let him be free from the necessity of doing something.

Meanwhile, positive face refers to the self-image of each person who wants what he does what he has or the values he believes (as a good thing, fun, rewarding, and so on).

An act of utterance can be a threat to the face. Such speech is defined by Brown and Levinson as the Face Threatening Act (FTA). To reduce that threat in communication we need to use language. Because there are two faces that are threatened negative face and positive face, then politeness can be divided into two, namely negative politeness (to keep negative face) and positive politeness (to keep positive face).

\section{Research Method}

In this study, the researcher uses a qualitative descriptive approach because this research does not use quantitative description (relating to numbers or statistics) and aims to describe or explain with words about object research. The study analyzed speech-acts including imitative entities especially those used by politicians while talking and being interviewed at TV One's Indonesian Lawyers club (ILC) on June 7, 2016. The data were obtained from a video recording of the Indonesian Lawyers' Club on 7 June 2016. Later, after observing the speech acts that appear 
in the video, the researcher analyzed and classified them into the types of speech acts based on the specch act theory stated by Wijana (1996: 30). The researcher then classified the speech acts referring to the imperative entity and classified them in the term of language politeness.

\section{Discussion}

In the program of the Indonesian Lawyers Club TV ONE on June $7^{\text {th }} 2016$, the speakers involved are the host (moderator), officials and politicians. They used speech acts in the communication. Well, in this case, the author tried to discuss the types of speech acts used in the event of Indonesian Lawyers Club edition June $7^{\text {th }}, 2016$. The theory used to discuss or examine the types of speech acts is the theory introduced by Wijana (1996: 30). He explained that types of speech act can be distinguished into direct speech acts and indirect speech acts, as well as literal and non-literal speech acts.

In the Indonesian Lawyers Club's on June $7^{\text {th }}, 2016$ edition, there are some speech-acts used by public officials and politicians categorized as follows:

\section{a) Direct Speech Act in ILC TV One}

Direct speech acts are a speech act in which the sentence means the same as the mind of speaker (Wijana, 1996: 30). For example, declarative sentence is used to tell something (information), interrogative sentence is used to ask something, and imperative sentenceis used to command, invite, request, or ask something. The examples of speech act found in Indonesian Lawyers Club June $7^{\text {th }} 2016$ edition is as follow:

1) Sebenarnya kita pengadilan dan kejaksaan tidak pada tataran oposisi

In this speech or utterance, the intonation is falling because it is a declarative statement.

2) Kita sama-sama sebagai aparat penegak hokum bekerjasama bagimana membuat Indonesia jadi lebih baik

In the act of this speech or utterance, the intonation of the narrative moves downward (falling) because it is a declarative sentence or declarative statement.

3) Tetapi kenapa dalam perkara yang di PN Surabaya yang menyangkut La Nyalla ini memang quote in quote menjadi what happen katanya?

In this speech or speech act, the intonation of the narrator rises because it signifies a question.

4) Masyarakat sekarang tidak bias diintervensi.

In this speech act or utterance, the intonation of the narrative moves downward (falling) because it is a declarative sentence or declarative statement.

\section{b) Non-Literal Speech Act in ILC TV One}

Non-literal speech act is a speech act which means not equal to or contrary to the meaning of words that make it (Wijana, 1996: 32). In the Indonesian Lawyers Club event, there is an example of a literary speech act. The speech was spoken by the Chief Prosecutor of East Java as follows:

"Biarkan semua masyarakat tahu bahwa La Nyala punya paman adalah Ketua Mahkamah Agung. Bagaimana hakim berani?"

From the example above, it can be seen that questions about "Bagaimana hakim berani?" That is not to question the courage of a judge. But this example is an affirmation of the distrust of judges to decide the case, because it turns out that the one who will be given the verdict is La Nyala a nephew of the Chief Justice of the Supreme Court.

c) Grice cooperative Principles in TheIndonesian Lawyers Club

Grice statesthat in using Grice Cooperated Principal, each speaker must obey 4 (four) conversational maxim, they are:

\section{Quantity Maxim}

Quantity Maxim requires each participant to contribute as much as needed by the interlocutor. In a conversation inside the Indonesian Lawyers Club, there are examples of the quantity maxim contained in speech used by Master of Ceremony and Politicians. An example is a conversation between Bung Karni Ilyas and Bung Taufik (Commission III of the Nasdem party) as follows:

Karni Ilyas : "Bung Taufik, Anda itu Komisi III?" 
Bung Taufik : "Komisi III."

From the above conversation, Bung Taufik (member of Commission III) gave enough answer or response as needed by Bung Karni Ilyas.

\section{Qualities Maxim}

This maxim requires that each participant of conversation should be based on sufficient evidence. In a conversation inside the Indonesian Lawyers Club, there are examples that do not fit the maxim of quantity rules, especially those contained in speech used by Master of Ceremony and Politicians. An example is a conversation between Bung Karni Ilyas and Bung Taufik (Commission III of the Nasdem party) as follows:

Karni Ilyas: "Bung juga SH [Sarjana Hukum] dong?"

Bung Taufik: "Saya belum selesai SH [Sarjana Hukum]."

Karni Ilyas: "Oh, it's not finished."

In the above conversation, it seems that Bung Taufik's answer violates the maxim of quality, because Bung Taufik did not give adequate answer to Bung Karni Ilyas's question. Bung Taufik should have replied that he did not get the SH (Bachelor of Law). In addition, the response from Bung Karni Ilyas in the form of speech "Oh, it's not finished" was insinuated to Bung Taufik for his answer about his unfinished Bachelor of Law.

The example is as follows:

Bung Taufik :"Masalah kepastian hokum maksudnya?"

Karni Ilyas : "Itu pertanyaan saya. Perlu nggak ada kepastian hokum dalam hal ini." From the above conversation, Bung Karni Ilyas gave a relevant response to the question statement from Bung Taufik related to legal certainty.

\section{Implementation Maxim}

The implementation maxim requires that each participant of conversation speaks directly, the conversation is not vague, not amboguous, and not exaggerated and must be coherent. An example of a statement that is in accordance with the maxim of implementation is a concise remark from Farid, a member of the Judicial Commission (KY) when describing the procedure of the report.

"Jika kemudian ada informasi yang diterima / kemudian ada laporan yang masuk, tentu akan melakukan proses tindak lanjut. Tentu dengan dasar atas pembuktian yang cukup untuk itu."

Table 1: The Form and Meaning of Sosiopragmatic Imperatif Entities in Indonesian Lawyers Club

\begin{tabular}{|c|c|c|c|c|}
\hline No. & Field & Imperative Form & $\begin{array}{c}\text { Context of } \\
\text { utterance }\end{array}$ & $\begin{array}{c}\text { Imperative } \\
\text { meaning }\end{array}$ \\
\hline 1. & $\begin{array}{l}\text { Politic } \\
\text { and law }\end{array}$ & $\begin{array}{l}\text { Ya, kita menganggap bahwa } \\
\text { putusan praperadilan dibawa oleh } \\
\text { hakim yang final \& binding di } \\
\text { tingkat pertama harus dihormati } \\
\text { oleh siapa pun }\end{array}$ & $\begin{array}{l}\text { Dituturkan oleh } \\
\text { seorang hakim } \\
\text { pengadilan } \\
\text { tanggal } 7 \text { Juni } \\
\text { 2016. Ini } \\
\text { berkaitan dengan } \\
\text { putusan pra- } \\
\text { peradilan yang } \\
\text { dimenangkan oleh } \\
\text { La Nyala Mataliti }\end{array}$ & Command \\
\hline
\end{tabular}


Table 1, cont.

\begin{tabular}{|c|c|c|c|c|}
\hline 2. & $\begin{array}{l}\text { Politic } \\
\text { and law }\end{array}$ & $\begin{array}{l}\text { Demikian juga pra-peradilan ini. } \\
\text { Bisa dikabulkan dan bisa ditolak. } \\
\text { Oleh sebab itulah, kalau kita } \\
\text { menghormati itu, saya kira tidak } \\
\text { akan berkepanjangan seperti ini. }\end{array}$ & $\begin{array}{l}\text { Dituturkan oleh } \\
\text { seorang hakim } \\
\text { pengadilan } \\
\text { tanggal } 7 \text { Juni } \\
\text { 2016. Ini } \\
\text { berkaitan dengan } \\
\text { putusan pra- } \\
\text { peradilan yang } \\
\text { dimenangkan oleh } \\
\text { La Nyala Mataliti }\end{array}$ & Advise \\
\hline 3. & $\begin{array}{l}\text { Politic } \\
\text { and law }\end{array}$ & $\begin{array}{l}\text { Kalaudemikian, } \\
\text { biarkanmasyarakatitumelihatben } \\
\text { aratautidak di pengadilan. } \\
\text { Silahkansaja, menurutsaya. }\end{array}$ & $\begin{array}{l}\text { Dituturkan oleh } \\
\text { Taufiq } \\
\text { (anggotaKomisi } \\
\text { III } \\
\text { daripartaiNasdem } \\
\text { ) pada tanggal } 7 \\
\text { Juni 2016. Ini } \\
\text { berkaitan dengan } \\
\text { pihak kejaksaan } \\
\text { yang tidak } \\
\text { menerima atas } \\
\text { putusan hakim } \\
\text { yang } \\
\text { memenangkan } \\
\text { gugatan pra- } \\
\text { peradilan La } \\
\text { Nyala. }\end{array}$ & Advise \\
\hline 4. & $\begin{array}{l}\text { Politic } \\
\text { and law }\end{array}$ & $\begin{array}{l}\text { Silahkan saja. Itu adalah hak } \\
\text { semuanya. Maka jutaan } \\
\text { masyarakat akan melihat hal } \\
\text { tersebut. }\end{array}$ & $\begin{array}{l}\text { Dituturkan oleh } \\
\text { Taufiq (anggota } \\
\text { Komisi III dari } \\
\text { partai Nasdem) } \\
\text { pada tanggal } 7 \\
\text { Juni 2016. Ini } \\
\text { berkaitan dengan } \\
\text { pihak kejaksaan } \\
\text { yang tidak } \\
\text { menerima atas } \\
\text { putusan hakim } \\
\text { yang } \\
\text { memenangkan } \\
\text { gugatan pra- } \\
\text { peradilan La } \\
\text { Nyala. }\end{array}$ & Advise \\
\hline
\end{tabular}


Table 1, cont.

\begin{tabular}{|c|c|c|c|c|}
\hline 5. & $\begin{array}{l}\text { Politic } \\
\text { and law }\end{array}$ & $\begin{array}{l}\text { Nah, berilah kesempatan pada } \\
\text { Jaksa untuk melihat hal tersebut. }\end{array}$ & $\begin{array}{l}\text { Dituturkan oleh } \\
\text { Taufiq (anggota } \\
\text { Komisi III dari } \\
\text { partai Nasdem) } \\
\text { pada tanggal } 7 \\
\text { Juni 2016. Ini } \\
\text { berkaitan dengan } \\
\text { pihak kejaksaan } \\
\text { yang tidak } \\
\text { menerima atas } \\
\text { putusan hakim } \\
\text { yang } \\
\text { memenangkan } \\
\text { gugatan pra- } \\
\text { peradilan La } \\
\text { Nyala. }\end{array}$ & Advise \\
\hline 6. & $\begin{array}{l}\text { Politic } \\
\text { and law }\end{array}$ & $\begin{array}{l}\text { Nah, karenanya, kita tentu } \\
\text { berharap bahwa forum malam } \\
\text { ini, malam ILC ini adalah bagian } \\
\text { untuk mengurai benang kusut } \\
\text { tersebut. }\end{array}$ & $\begin{array}{l}\text { Dituturkan oleh } \\
\text { Nasri Jamil } \\
\text { (anggota Komisi } \\
\text { III dari PKS). Ini } \\
\text { berkaitan dengan } \\
\text { acara ILC yang } \\
\text { membahas kasus } \\
\text { pra-peradilan La } \\
\text { Nyala Mataliti. }\end{array}$ & $\begin{array}{l}\text { Asking for } \\
\text { (Request) }\end{array}$ \\
\hline 7. & $\begin{array}{l}\text { Politic } \\
\text { and law }\end{array}$ & $\begin{array}{l}\text { Perlu ada suatu kesamaan visi } \\
\text { dan persepsi soal pra-peradilan. }\end{array}$ & $\begin{array}{l}\text { Dituturkan oleh } \\
\text { Nasri Jamil } \\
\text { tanggal } 7 \text { Juni } \\
\text { 2016. Ini } \\
\text { berkaitan dengan } \\
\text { putusan pra- } \\
\text { peradilan yang } \\
\text { dimenangkan oleh } \\
\text { La Nyala Mataliti }\end{array}$ & $\begin{array}{l}\text { Asking for } \\
\text { (Request) }\end{array}$ \\
\hline 8. & $\begin{array}{l}\text { Politic } \\
\text { and law }\end{array}$ & $\begin{array}{l}\text { Jadi, itu memang harus diatur } \\
\text { semuanya. Maka harus ada } \\
\text { kesamaan visi dan persepsi. }\end{array}$ & $\begin{array}{l}\text { Dituturkan oleh } \\
\text { Nasri Jamil } \\
\text { tanggal } 7 \text { Juni } \\
\text { 2016. Ini } \\
\text { berkaitan dengan } \\
\text { putusan pra- } \\
\text { peradilan yang } \\
\text { dimenangkan oleh } \\
\text { La Nyala Mataliti }\end{array}$ & Command \\
\hline
\end{tabular}


Table 1, cont.

\begin{tabular}{|c|c|c|c|c|}
\hline 9. & $\begin{array}{l}\text { Politic } \\
\text { and law }\end{array}$ & $\begin{array}{l}\text { Mari kita bangun sama-sama } \\
\underline{\text { (sistem). }}\end{array}$ & $\begin{array}{l}\text { Dituturkan oleh } \\
\text { Profesor Takdir } \\
\text { Rahmadi, Hakim } \\
\text { Agung MA, } \\
\text { tanggal 7 Juni } \\
\text { 2016. Ini } \\
\text { berkaitan dengan } \\
\text { putusan pra- } \\
\text { peradilan yang } \\
\text { dimenangkan oleh } \\
\text { La Nyala Mataliti } \\
\end{array}$ & Advise \\
\hline 10 . & $\begin{array}{l}\text { Politic } \\
\text { and law }\end{array}$ & $\begin{array}{l}\text { Carilah keadilan menurut cara- } \\
\text { cara perdamaian mediasi. }\end{array}$ & $\begin{array}{l}\text { Dituturkan oleh } \\
\text { Artidjo Alkostar, } \\
\text { Hakim Agung } \\
\text { MA, tanggal } 7 \\
\text { Juni 2016. Ini } \\
\text { berkaitan dengan } \\
\text { putusan pra- } \\
\text { peradilan yang } \\
\text { dimenangkan oleh } \\
\text { La Nyala Mataliti }\end{array}$ & Advise \\
\hline 11. & $\begin{array}{l}\text { Politic } \\
\text { and law }\end{array}$ & Bergaullah dengan orang bijak. & $\begin{array}{l}\text { Dituturkan oleh } \\
\text { ArtidjoAlkostar, } \\
\text { Hakim Agung } \\
\text { MA, tanggal } 7 \\
\text { Juni 2016. Ini } \\
\text { berkaitan dengan } \\
\text { putusan pra- } \\
\text { peradilan yang } \\
\text { dimenangkan oleh } \\
\text { La Nyala Mataliti }\end{array}$ & Advise \\
\hline 12. & $\begin{array}{l}\text { Politic } \\
\text { and law }\end{array}$ & $\begin{array}{l}\text { Jadi, hal-hal semacam itu perlu } \\
\text { diluruskan. Tidak boleh } \\
\text { mencampuri kebebasan hakim. }\end{array}$ & $\begin{array}{l}\text { Dituturkan oleh } \\
\text { ArtidjoAlkostar, } \\
\text { Hakim Agung } \\
\text { MA, tanggal } 7 \\
\text { Juni 2016. Ini } \\
\text { berkaitan dengan } \\
\text { putusan pra- } \\
\text { peradilan yang } \\
\text { dimenangkan oleh } \\
\text { La Nyala Mataliti }\end{array}$ & Advise \\
\hline 13. & $\begin{array}{l}\text { Politic } \\
\text { and law }\end{array}$ & $\begin{array}{l}\text { Berhentilah sudah. Sekali lagi, } \\
\text { berhentilah sudah berspekulasi } \\
\text { dengan asumsi-asumsi putusan } \\
\text { praperadilan yang di } 3 \text { pengadilan } \\
\text { negeri Surabaya itu antarapemohon } \\
\text { material dengan pimpinan } \\
\text { peradilan. }\end{array}$ & $\begin{array}{l}\text { Dituturkan oleh } \\
\text { Doktor Said } \\
\text { Karim, tanggal } 7 \\
\text { Juni 2016. Ini } \\
\text { berkaitan dengan } \\
\text { putusan pra- } \\
\text { peradilan yang } \\
\text { dimenangkan oleh } \\
\text { La Nyala Mataliti }\end{array}$ & Prohibition \\
\hline
\end{tabular}


Table 1, cont.

\begin{tabular}{|c|c|c|c|c|}
\hline 14. & $\begin{array}{l}\text { Politic } \\
\text { and law }\end{array}$ & $\begin{array}{l}\text { Apalagi ini dalam suasana bulan } \\
\text { ramadhan, semestinya kita berhati } \\
\text { bersih, jernih dan melepaskan } \\
\text { diri dari asumsi-asumsi negative } \\
\text { yang tidak bias } \\
\text { dipertanggungjawabkan. }\end{array}$ & $\begin{array}{l}\text { Dituturkan oleh } \\
\text { Doktor Said } \\
\text { Karim, tanggal } 7 \\
\text { Juni 2016. Ini } \\
\text { berkaitan dengan } \\
\text { putusan pra- } \\
\text { peradilan yang } \\
\text { dimenangkan oleh } \\
\text { La Nyala Mataliti }\end{array}$ & Advise \\
\hline 15. & $\begin{array}{l}\text { Politic } \\
\text { and law }\end{array}$ & $\begin{array}{l}\text { Saya sarankan jika mungkin pada } \\
\text { Bapak Majelis Hakim yang mulia, } \\
\text { ini dibuatkan dalam pelatihan- } \\
\text { pelatihan. }\end{array}$ & $\begin{array}{l}\text { Dituturkan oleh } \\
\text { Doktor Said } \\
\text { Karim, tanggal } 7 \\
\text { Juni 2016. Ini } \\
\text { berkaitan dengan } \\
\text { putusan pra- } \\
\text { peradilan yang } \\
\text { dimenangkan oleh } \\
\text { La Nyala Mataliti }\end{array}$ & Suggestion \\
\hline
\end{tabular}

From the table above, the emergence of the imperative that appears 10 times is the meaning of imperatif in the form of advice. Thus, in the realm of law and politics, the sociopragmatic meaning of suggestion is the most common meaning because the frequency of occurrence is most dominant.

\section{The Forms of Sociopragmatics Imperative Politeness}

In terms of politeness, it can be said that the meaning of sociopragmatic imperative in the form of recommendation has a high degree of politeness compared with other imperative forms. In the realm of law and politics, the sociopragmatic forms of suggestion can be shown in the following examples.

1) Demikian juga pra-peradilan ini. Bisa dikabulkan dan bisa ditolak. Oleh sebab itulah, kalau kita menghormati itu, saya kira tidak akan berkepanjangan seperti ini.

2) Biarkan nmasyarakat itu melihat benar atau tidak di pengadilan. Silahkan saja, menurut saya.

3) Silahkan saja. Itu adalah hak semuanva. Maka jutaan masyarakat akan melihat hal tersebut

4) Nah, berilah kesempatan pada Jaksa untuk melihat hal tersebut

5) Perlu ada suatu kesamaan visi dan persepsi soal pra-peradilan.

6) Carilah keadilan menurut cara-cara perdamaian mediasi

7) Mari kita bangun sama-sama (system).

8) Bergaullah dengan orang bijak

9) Jadi, hal-hal semacam itu perlu diluruskan. Tidak boleh mencampuri kebebasan hakim

10) Apalagi ini dalam suasana bulan ramadhan, semestinya kita berhati bersih, jernih dan melepaskan diri dari asumsi-asumsi negative yang tidak bias dipertanggungjawabkan.

The meaning of sociopragmatics imperative in the form of suggestions as examplified above does not have a focus load on the side of the member who is recommended. That is, because the meaning is in the form of advice. There is nothing in Brown and Levinson's point of view (1987) is a humiliated face or lowered his self esteem. Since none of the parties are defeated or 
humiliated their pride, the imperative speech or entity in the form of such a suggestion is of high politeness. That is, the faces of all parties involved are equally rescued.

\section{Conclusion and suggestion}

From the above discussions and descriptions, it can be concluded that in the event of Indonesian Lawyers Club TV ONE edition June $7^{\text {th }} 2016$ there are pragmatic forms which are applied, those are: direct speech act, literal speech act and non-literal speech act, the principles of Grice's cooperation, and the maxims, imperative entities, and the principles of politeness.

Meanwhile, the suggestions that can be put forward for political languages are the languages used should not be exaggerated so as not to contradict the maxim of relevance contained in the Principles of Grice Cooperation in Pragmatics.

\section{References}

Archer, et al. 2012. Pragmatics: An advanced resource book for students. Great Britain: Routledge Applied Linguistics.

Asim, G. 1994. Kesantunan Negatif di KalanganDwibahasawan Indonesia-Jawa di Jakarta: Kajian Sosiopragmatik (PELLBA 7). Jakarta: Lembaga Bahasa UnikaAtma Jaya.

Black, E. 2011. Stilistika Pragmatis, Terjemah. Bandung: Pustaka Pelajar.

Coupland, N. \& Jaworski, A. 1997. Sociolinguistics, A Reader and Coursebook. The United States of America: St. Martin's Press, Inc.

Holmes, J. 1992. An Introduction to Sociolinguistics. UK: Longman Group UK.

Kamus Besar Bahasa Indonesia ( $3^{\text {rd }}$ ed). 2002. Pusat Bahasa Departemen Pendidikan Nasional. Jakarta: Balai Pustaka. ISBN: 979-407-182-X.

Leech, G. 1993. Prinsip-Prinsip Pragmatik. (M.D.D Oka, Trans). Jakarta: Universitas Indonesia Press.

Matthews, P.H. 2014. The Concise Oxford Dictionary of Linguistics $\left(3^{\text {rd }}\right.$ ed). Oxford: Oxford University Press.

Rustono. 1999. Pokok-Pokok Pragmatik. Semarang: CV. IKIP Semarang Press.

Watt, J. R. 2003. Politeness. Australia: Cambridge University Press.

Wijana, I D. P. 1996. Dasar-Dasar Pragmatik. Yogyakarta. Penerbit Andi.

Wijana, I. D. P. dan Rohmadi, M. 2011. Analisis Wacana Pragmatik, Kajian Teori dan Analisis. Surakarta: Yuma Pustaka.

Yule, G. 1996. Pragmatics. Oxford: Oxford University Press. 